\title{
Efekty restrukturyzacji słupskiego ośrodka przemysłowego w okresie wdrażania gospodarki rynkowej (na wybranych przykładach)
}

Transformacja systemu ekonomicznego kraju, której celem jest osiąnnięcie warunków właściwych gospodarce rynkowej, wymusiła konieczność restrukturyzacji wielu dziedzin życia społeczno-gospodarczego w Polsce. Ukształtowane bowiem w okresie powojennym układy gospodarcze, stosownie do ówczesnych potrzeb, koncepcji, możliwości i warunków zewnętrznych, w większości okazały się nieprzydatne w warunkach zmienionego otoczenia, innych potrzeb i priorytetów rozwojowych. Wymagały zatem restrukturyzacji rozumianej jako proces przebudowy struktury. Zaznaczyć należy, że przemysł jest jednym z tych sektorów (obok rolnictwa uspołecznionego), w których przestrzenne skutki transformacji zaznaczają się bardzo silnie. Związane jest to nie tylko ze zmianą wewnętrznych mechanizmów gospodarowania, ale także z globalnymi procesami przemian (często również określane mianem transformacji), coraz wyraźniej oddziałującymi na strukturę i powiązania przestrzenne przemysłu w Polsce.

Dotychczasowe studia dotyczące transformacji obejmują najczęściej jej aspekty makroekonomiczne i ocenę zastosowanych strategii zmian (np. terapia szokowa). Z kolei na poziomie mikroekonomicznym większość badań empirycznych przedsiębiorstw pomija efekty restrukturyzacji (np. zmian strukturalnych, tendencji w zakresie przemian struktury gałęziowej i wielkościowej, a przede wszystkim przemian w użytkowaniu i zagospodarowaniu terenów przemysłowych). Odczuwa się zatem potrzebę opracowań próbujących wniknąć głębiej w mechanizm zmian transformacyjnych, adaptacji przedsiębiorstw do nowych warunków gospodarowania oraz kształtowania się nowych relacji przestrzennych.

W świetle powyższych przesłanek, celem niniejszego artykułu jest analiza przemian struktury przestrzenno-gałęziowej przemysłu Słupska ze szczególnym uwzględnieniem lat 1995-2003. Ważnym elementem jest również próba przedstawienia form zagospodarowania majątku największych zakładów przemysłowych, które poddane zostały procesowi restrukturyzacji oraz przemian w użytkowaniu terenów przemysłowych Słupska. Na marginesie pragniemy zaznaczyć, że prezentowany artykuł nawiązuje tematycznie i przestrzennie do wcześniejszych opracowań współautora o funkcji Koszalina i Słupska w regionalnej sieci osadniczej [Rydz 1990], roli i funkcji Słupska na tle sieci osadniczej Środkowego Wybrzeża [Rydz, Zaleski 1992], procesów transformacji słupskiego ośrodka przemysłowego w latach 
1990-1995 [Rydz, Jażewicz 1997] oraz zmian w strukturze użytkowania ziemi na przykładzie Słupska i Szczecinka [Rydz 1999].

\section{OGÓLNA CHARAKTERYSTYKA SŁUPSKIEGO OŚRODKA PRZEMYSŁOWEGO}

W okresie powojennym procesy industrializacji należały do głównych czynników przemian struktury przestrzennej kraju, prowadząc równocześnie do ukształtowania i specjalizacji terytorialnego podziału pracy [Rajman 2001]. Działalność produkcyjna stała się głównym czynnikiem miastotwórczym i stymulatorem rozwoju gospodarczego wielu miast, w których wykształciły się chłonne rynki pracy, silnie powiązane z bliższym i dalszym zapleczem.

Istotną przeszkodą w rozwoju przemysłu po wyzwoleniu były zniszczenia wojenne. Potencjał przemysłowy Słupska uszczuplony w toku wojny (stopień zniszczeń wojennych wynosił około $60 \%$ ) oraz w wyniku demontażu na rzecz odszkodowań wojennych stanowił bazę, którą trzeba było poddać zasadniczej restrukturyzacji i rozbudowie. Odbudowa i uruchomienie przemysłu w Słupsku były zatem jednym z najbardziej skomplikowanych problemów, przed którymi stanęły władze polskie. Odbudowa nie mogła być wiernym odbiciem przeszłości, należało bowiem uwzględniać odmienne warunki kooperacji z innymi przemysłami, poważne zmiany w sytuacji surowcowej, wzgląd na strukturę przemysłu reszty kraju.

W całokształcie zagadnień lokalizacji przemysłu w Słupsku istotną rolę odegrało środowisko geograficzne. Jego czynniki w zasadniczy sposób oddziaływały na lokalizację przemysłu. Największą rolę spośród nich odegrały warunki budowlane, stosunki wodne, surowce i klimat. Powodowało to znaczny stopień skupienia zakładów przemysłowych na terenie miasta (ryc. 1). Jak wynika z przeprowadzonych analiz najkorzystniejsze warunki dla budownictwa wielokondygnacyjnego i również przemysłowego występują w zachodniej i południowo-zachodniej części miasta na osiedlach: Piastów, Nadrzecze, Bałtyckie i Batorego.

Jednym z ważnych elementów lokalizacji przemysłu w ośrodku słupskim był także układ komunikacyjny, który wspólnie z wcześniej wspomnianymi warunkami naturalnymi wyraźnie wpłynął na koncentrację przemysłu w okresie powojennym.

W okres nowego rozwoju społeczno-gospodarczego, charakteryzującego się m.in. powrotem do gospodarki rynkowej, Słupsk wkroczył z potencjałem przemysłowym zorganizowanym w 155 zakładach państwowych i spółdzielczych, w których w 1988 r. pracowało ponad 13,9 tys. osób (w 1980 w przemyśle pracowało około 15,5 tys. osób), czyli ponad 37\% czynnych zawodowo mieszkańców tego miasta i niemal 17\% ogółu osób, które tu mieszkały. Jest to wskaźnik dość wysoki, zważywszy na fakt, że Słupsk był zawsze miastem o kilku wykształconych funkcjach (np. w zakresie szkolnictwa, ochrony zdrowia, administracji itd.). Udział zatrudnionych w przemyśle Słupska, mimo że w latach 80. XX wieku systematycznie malał, to i tak do 1990 r. stanowił główne źródło utrzymania i życiodajną funkcję miasta. Działalność produkcyjna była nie tylko głównym czynnikiem miastotwórczym, ale ukształtowała również silne powiązania z bliższym i dalszym zapleczem poprzez codzienne dojazdy do pracy do zakładów przemysłowych, które w 1983 r. wynosiły 3093 osoby na ogólną liczbę 7801 dojeżdżających codziennie do Słupska [Rydz 1990].

Obserwowany w latach 1965-1980 wzrost zatrudnienia w przemyśle był głównie wynikiem budowy nowych zakładów. Największym osiaggnięciem tego okresu było przekazanie do eksploatacji trzech największych zakładów: Komunalnego Przedsiębiorstwa Naprawy 


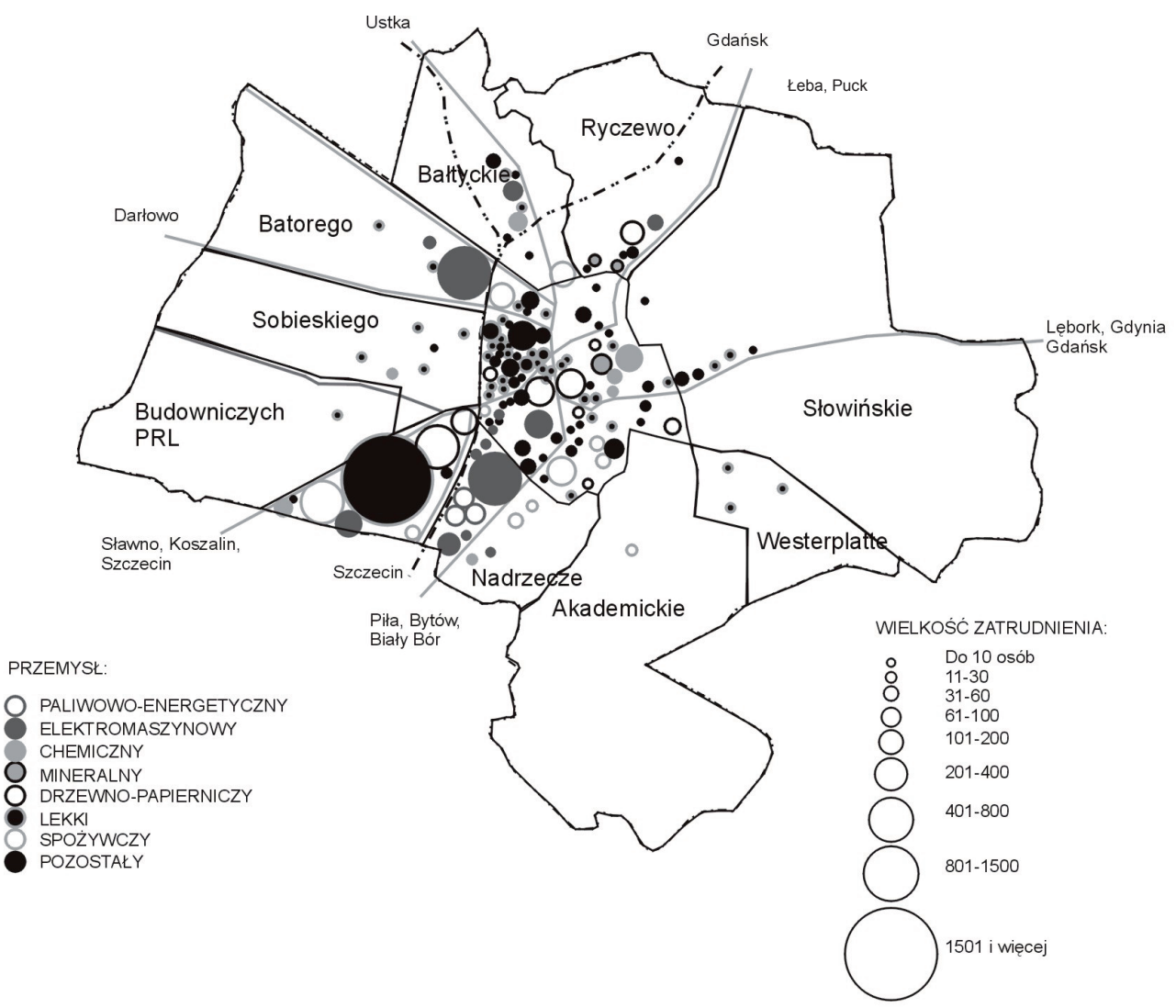

Ryc. 1. Rozmieszczenie zakładów przemysłowych według branży i wielkości zatrudnienia w Słupsku w $1980 \mathrm{r}$.

Źródło: E. Rydz, Funkcje Koszalina i Słupska w regionalnej sieci osadniczej, WSP, Słupsk 1990

Autobusów „Kapena” (w 1968), Północnych Zakładów Przemysłu Skórzanego „Alka” (w 1969) i Zakładów Sprzętu Okrętowego „Sezamor” (w 1970). Do największych przedsiębiorstw przemysłowych Słupska w połowie lat 80. należały zatem: Północne Zakłady Przemysłu Skórzanego „Alka” (3600 zatrudnionych), Słupskie Fabryki Mebli (1850), Fabryka Maszyn Rolniczych „Famarol” (ok. 1000), Komunalne Przedsiębiorstwo Naprawy Autobusów „Kapena” (1000) i Fabryka Cukrów „Pomorzanka” (890). Na terenie miasta koncentrowało się około 49,0\% zatrudnionych w przemyśle byłego województwa słupskiego, zaś udział w produkcji globalnej przemysłu całego regionu wynosił ponad $62 \%$.

Innym wyznacznikiem roli przemysłu ośrodka słupskiego jest fakt, że wyprodukowano tu w 1989 r. około 3,5\% (1382 tys. par) ogólnokrajowej produkcji obuwia i około 8,2\% krajowej produkcji maszyn i urządzeń rolniczych, zaś udział w produkcji mebli w skali kraju wynosił około 2,2\%. Specyfiką przemysłu ośrodka słupskiego było w przeszłości wyraźne zróżnicowanie branżowe [Rydz, Zaleski 1992]. Największy udział w potencjale przemysłowym miasta w 1988 r. posiadał przemysł skórzany $(27,0 \%)$, spożywczy $(15,6 \%)$, drzewny $(15,1 \%)$ i środków transportu $(13,6 \%)$, jeśli za miernik przyjmiemy liczbę zatrudnionych 
(ryc. 2). Nieco inaczej kształtowała się struktura gałęziowa, gdy za miernik przyjmie się wartość produkcji globalnej. Wówczas największy (1989) był udział wartości produkcji przemysłu spożywczego $(27,5 \%)$, maszynowego $(18,6 \%)$, skórzanego $(15,1 \%)$, drzewnego $(14,6 \%)$ i środków transportu $(13,3 \%)$.

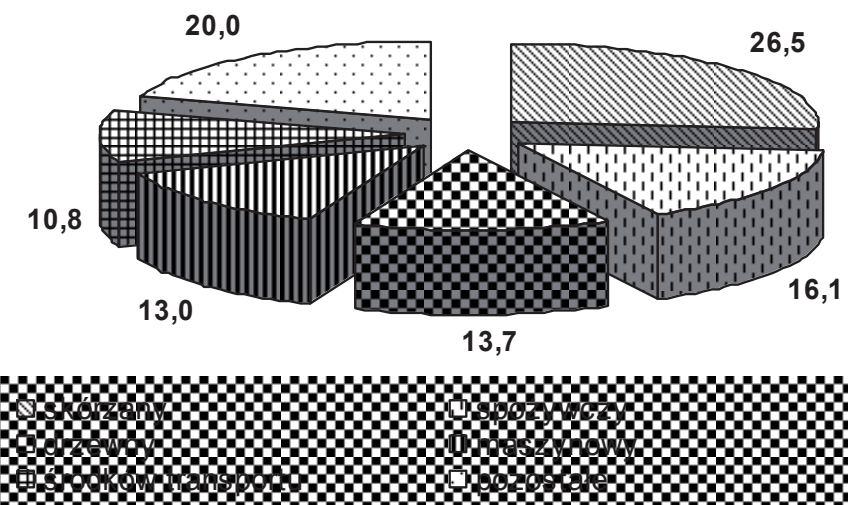

Ryc. 2. Struktura gałęziowa przemysłu w Słupsku według zatrudnienia w $1988 \mathrm{r}$.

\section{ZMIANY STRUKTURALNE PRZEMYSŁU OŚRODKA SŁUPSKIEGO}

W okresie transformacji gospodarki polskiej występują istotne różnice w zachowaniu podmiotów gospodarczych różnych sektorów i gałęzi. Miarami zmian strukturalnych są m.in.: tempo przekształceń własnościowych, zmiany w liczbie i strukturze podmiotów gospodarczych oraz pozyskanie kapitału zagranicznego i jego skłonność do inwestowania.

Dokonane analizy struktury własnościowej i organizacyjnej przedsiębiorstw przemysłowych Słupska wskazują, że do końca 2003 r. około 98\% zakładów uległo przekształceniom własnościowym. Pierwszym sprywatyzowanym przedsiębiorstwem był Browar w Słupsku, który wchodził w skład zespołu Koszalińskich Zakładów Piwowarskich. W kolejnych latach przekształceniom własnościowym poddane zostały wszystkie wiodące do niedawna zakłady przemysłowe Słupska, np. Północne Zakłady Przemysłu Skórzanego „Alka”, Słupskie Zakłady Przemysłu Ziemniaczanego „Stolon”, Fabryka Cukierków „Pomorzanka”, Słupska Fabryka Mebli. Najczęściej stosowaną formą prywatyzacji było przekształcenie w spółkę akcyjną Skarbu Państwa lub w spółkę z ograniczoną odpowiedzialnością. Cztery przedsiębiorstwa ze Słupska o dość niezłej kondycji finansowej (Komunalne Przedsiębiorstwo Naprawy Autobusów „Kapena”, Zakłady Urządzeń Okrętowych „Sezamor”, Fabryka Maszyn Rolniczych „Agromet-Famarol” oraz Przedsiębiorstwo Zbożowo-Młynarskie) wytypowano do programu Powszechnej Prywatyzacji Narodowych Funduszy Inwestycyjnych [Rydz, Jażewicz 1997].

Przebieg procesów prywatyzacyjnych przemysłu w ośrodku słupskim zaznaczył się obok wyraźnego spadku liczby pracujących (około 30\% w latach 1988-2003) dość istotnymi 
zmianami struktury gałęziowej (tab. 1). W ukształtowanej zasadniczo w latach 70. strukturze przemysłu nastąpiły w okresie transformacji dość wyraźne zmiany. Z jednej strony - wzrost znaczenia przemysłu chemicznego w wyniku uruchomienia w latach 80 . prywatnej firmy „Dom-Plast”, produkującej artykuły z tworzyw sztucznych. Z drugiej zaś w kolejnych latach - znaczny rozwój tej firmy (m.in. w wyniku wykupienia całości udziałów przez koncern amerykański).

Tabela 1. Struktura gałęziowa przemysłu Słupska według zatrudnienia i liczby pracujących w latach 1988-2003

\begin{tabular}{|l|c|r|r|r|r|r|}
\hline \multirow{2}{*}{ Gałęzie przemysłu } & \multicolumn{2}{|c|}{1988} & \multicolumn{2}{c|}{1995} & \multicolumn{2}{c|}{2003} \\
\cline { 2 - 7 } & $\begin{array}{c}\text { liczba } \\
\text { zatrudnionych }\end{array}$ & $\%$ & $\begin{array}{c}\text { liczba } \\
\text { zatrudnionych }\end{array}$ & $\%$ & $\begin{array}{c}\text { liczba } \\
\text { zatrudnionych }\end{array}$ & $\%$ \\
\hline ogółem & 13863 & 100,0 & 10758 & 100,0 & 9658 & 100,0 \\
metalowy & 179 & 1,3 & 373 & 3,5 & 431 & 4,5 \\
maszynowy & 1802 & 13,0 & 1104 & 10,3 & 754 & 7,8 \\
środków transportu & 1505 & 10,8 & 1142 & 10,6 & 1473 & 15,2 \\
chemiczny & 176 & 1,3 & 903 & 8,4 & 1612 & 16,7 \\
szklarski & 91 & 0,7 & 27 & 0,2 & 35 & 0,4 \\
materiałów budowlanych & 78 & 0,6 & 128 & 1,2 & 329 & 3,4 \\
drzewny & 1896 & 13,7 & 1900 & 17,7 & 1155 & 12,0 \\
papierniczy & 71 & 0,5 & 152 & 1,4 & 145 & 1,5 \\
odzieżowy i włókienniczy & 626 & 4,5 & 766 & 7,1 & 312 & 3,2 \\
skórzany & 3676 & 26,5 & 1148 & 11,0 & 1439 & 14,8 \\
spożywczy & 2235 & 16,1 & 1505 & 14,0 & 1039 & 10,8 \\
poligraficzny & 119 & 0,8 & 46 & 0,4 & 204 & 2,1 \\
pozostałe branże przemysłu & 1409 & 10,2 & 1528 & 14,2 & 730 & 7,6 \\
\hline
\end{tabular}

Źródło: E. Rydz, J. Zaleski, Rola i funkcje Stupska na tle sieci osadniczej Środkowego Wybrzeża, WSP, Słupsk 1992, s. 74; Kartoteka dla systemu DG-1, WUS, Słupsk 1995; Tablice wynikowe. Podmioty gospodarcze w systemie REGON, US, Slupsk 2004

Aktualnie dawny „Dom-Plast”, a obecny „Newell Rubbermaind” jest jednym z największych przedsiębiorstw produkcyjnych w Słupsku (650 zatrudnionych w 2003). Dotychczasowy przebieg procesu restrukturyzacji gospodarki Słupska wskazuje również na wzrost (o 4,6 punktu procentowego w latach 1995-2003) znaczenia w ogólnej strukturze przemysłu działu zajmującego się produkcją środków transportu. Jest to m.in. wynik uruchomienia w słupskiej „Kapenie” montowni ciagników siodełkowych i autobusów miejskich i utworzenia spółki Scania-Kapena z udziałem kapitału zagranicznego.

Miarą przekształceń, jakie zaszły w ostatnich latach, w przemyśle Słupska jest dość istotne zmniejszenie tradycyjnych do niedawna w gospodarce miasta gałęzi przemysłu m.in. przemysłu drzewnego, skórzanego i spożywczego. Zjawisko to spowodowane zostało wyraźnym ograniczeniem zatrudnienia w Fabryce Obuwia „Alka” z 1249 osób w 1994 r. do 341 osób na koniec 2002 r., likwidacją Słupskich Fabryk Mebli (2002) oraz Zakładów Przemysłu Mięsnego (1997).

Jeszcze bardziej radykalne zmiany zaszły w strukturze wielkościowej zakładów przemysłowych. Jak już podano wcześniej, w 1988 r. działało w Słupsku 155 państwowych i spółdzielczych zakładów przemysłowych, w których pracowało ponad 13,8 tys. osób. Dawało to 
statystyczny wskaźnik 90 osób na jeden zakład, choć charakterystyczną cechą słupskiego przemysłu w tym okresie, jak na warunki miasta tej kategorii wielkościowej, były wielkie zakłady zatrudniające ponad 500 osób.

Informacje statystyczne zebrane w systemie REGON wskazują, że w końcu 2003 r. były w Słupsku zarejestrowane ogółem 984 podmioty gospodarcze. Podmioty te zatrudniały łącznie 9658 pracowników, co daje statystycznie wskaźnik 9,8 osoby zatrudnionej przez jeden podmiot gospodarczy (tab. 2).

Tabela 2. Struktura przedsiębiorstw przemysłowych Słupska według liczby pracowników w $2003 \mathrm{r}$.

\begin{tabular}{|l|r|r|r|r|}
\hline \multirow{2}{*}{$\begin{array}{c}\text { Wielkość } \\
\text { przedsiębiorstw }\end{array}$} & \multicolumn{2}{|c|}{ Przedsiębiorstwa } & \multicolumn{2}{c|}{ Pracujący } \\
\cline { 2 - 5 } & liczba & $\%$ & liczba & $\%$ \\
\hline Ogółem & 984 & 100,0 & 9658 & 100,0 \\
w tym: & 821 & 83,3 & 1372 & 14,2 \\
$0-5$ & 40 & 4,1 & 287 & 3,0 \\
$6-9$ & 55 & 5,6 & 792 & 8,2 \\
$10-20$ & 38 & 3,9 & 1326 & 13,7 \\
$21-50$ & 12 & 1,3 & 947 & 9,8 \\
$51-100$ & 9 & 0,9 & 1297 & 13,4 \\
$101-120$ & 9 & 0,9 & 3637 & 62,3 \\
powyżej 200 & &
\end{tabular}

Źródło: Tablice wynikowe podmiotów gospodarczych w systemie REGON, US, Słupsk 2004

Preferowany w latach 70. wzrost stopnia koncentracji zatrudnienia w dużych zakładach nie sprostał w pełni wymogom gospodarki rynkowej po 1989 r. Wyrazem tego jest nie tylko ogólny spadek zatrudnienia w przemyśle Słupska, ale również istotnie niższy stopień koncentracji pracujących w dużych zakładach. Bardzo wysoka redukcja zatrudnienia w największych zakładach przemysłowych Słupska spowodowała, że aktualnie żadne z przedsiębiorstw przemysłowych nie przekracza liczby 700 pracujących.

W trwającym od 1989 r. okresie transformacji pewnym zmianom uległa struktura przestrzenna przemysłu Słupska, która z jednej strony jest wynikiem likwidacji zakładów (np. Zakładów Mięsnych, Słupskiej Fabryki Mebli), a także wyraźnego ograniczenia zatrudnienia, z drugiej zaś - uruchomienia nowych przedsiębiorstw. Generalnie zachowany został jednak ukształtowany $\mathrm{w}$ okresie przyspieszonej industrializacji w latach 70 . układ przestrzenny (ryc. 3) przemysłu Słupska z dominacją jego koncentracji na osiedlach: Stare Miasto, Nadrzecze, Piastów. Na podkreślenie zasługuje fakt, że w ostatnich pięciu latach nastąpiła dalsza koncentracja przemysłu na osiedlu Nadrzecze, głównie przez uruchomienie nowych przedsiębiorstw położonych wzdłuż ulicy Poznańskiej (drogi wylotowej w kierunku Piły i Poznania) oraz na osiedlu Bałtyckim, na terenie którego położona jest część Słupskiej Specjalnej Strefy Ekonomicznej. Znajdują się tu m.in. nowo uruchomione zakłady: produkcji okien z PCV „Bajcar”, produkcji szyb samochodowych i drzwi szklanych „NordGlass”, przetwórstwa rybnego „Łosoś”, przemysłu mięsnego „Perelstein”, fabryka okien M\&S, firma budowlana „Dombet”.

Przedstawiona analiza wskazuje, że przemysł ośrodka słupskiego w warunkach gospodarki rynkowej przechodzi do fazy dekoncentracji swojej działalności. Wpływają na to wio- 
dące tendencje do ograniczenia działalności produkcyjnej w dużych przedsiębiorstwach oraz tańsza ich lokalizacja w strefie podmiejskiej, przykładem są m.in. nowo powstałe zakłady produkcji obuwia („Nord”, „Gino Rossi”), mebli - Flair Poland (w Kobylnicy) oraz mleczarnia należąca obecnie do firmy „Lacpol” (dawniej „Nestle”).

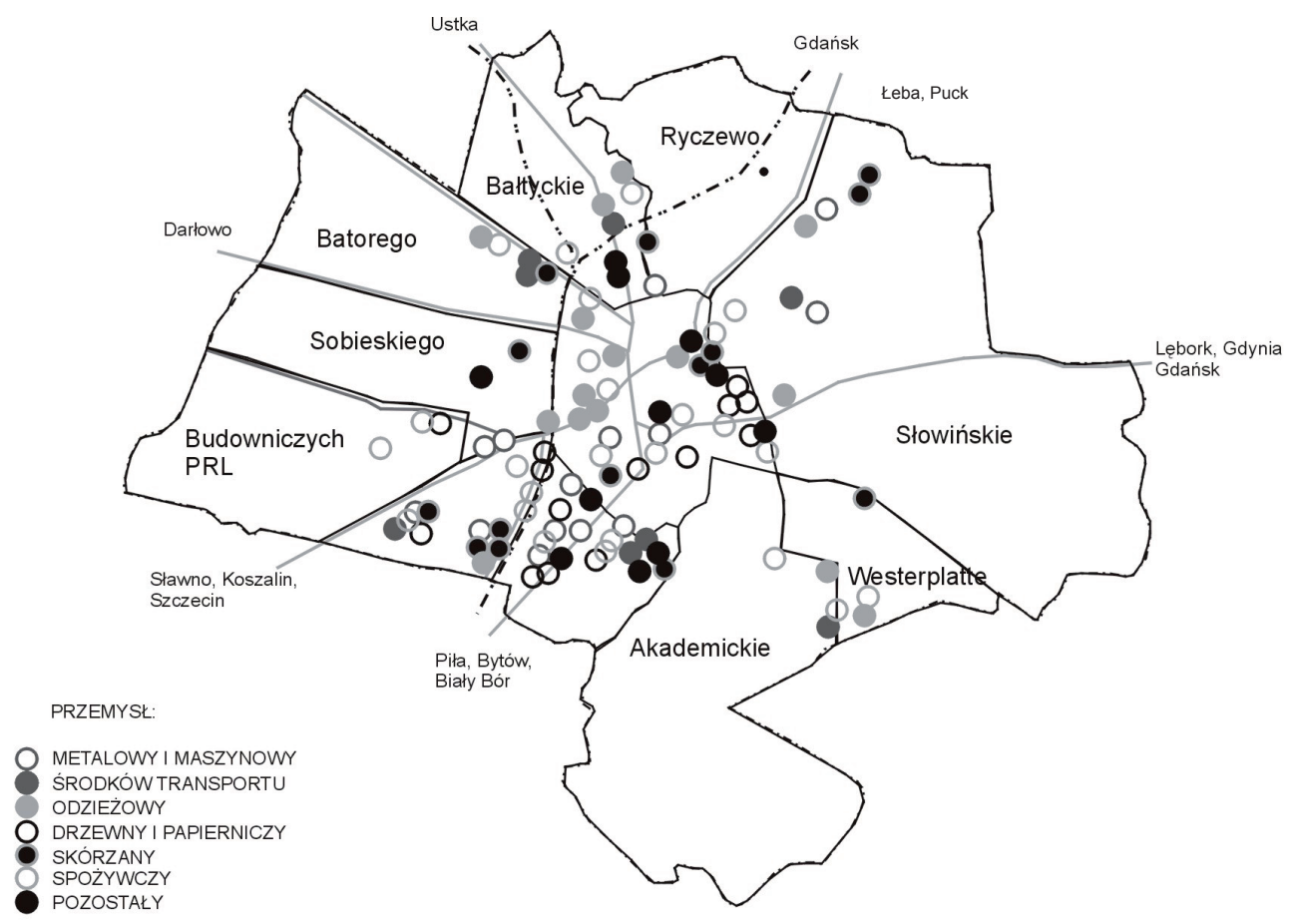

Ryc. 3. Rozmieszczenie zakładów przemysłowych według branży w Słupsku w 2002 r.

Źródło: Opracowanie własne

\section{PRZEKSZTAŁCENIA TERENÓW PRZEMYSŁOWYCH.}

SKALA PROBLEMU I PRZYKŁADY PRZEKSZTAŁCEŃ

Szybkie przemiany gospodarcze zachodzące w latach 90. oraz dziedzictwo, często ekstensywnie wykorzystanych w przeszłości, terenów fabrycznych spowodowały pojawienie się w polskich miastach rozległych niekiedy terenów poprzemysłowych. Skala tego zjawiska choć szczególnie duża jest w okręgach i ośrodkach, w których znaczny udział miały branże tradycyjne [Domański 2001], występuje również z różnym nasileniem w średniej wielkości ośrodkach o często zróżnicowanej strukturze gałęziowej przemysłu. Potwierdzeniem tego faktu mogą być badania, jakie przeprowadzono w największych do niedawna zakładach przemysłowych na terenie miasta Słupska.

Generalnie rozróżnia się trzy rodzaje nieużytkowanych terenów przemysłowych [Gasidło 1998; Domański 2000]: 
- formalnie lub faktycznie porzuconych przez właściciela lub dysponenta, tzw. ugorów;

- przetrzymywanych przez dotychczasowego właściciela w nadziei ewentualnego ponownego wykorzystania w dotychczasowej funkcji;

- „odłogowych” w oczekiwaniu na korzystne możliwości gospodarowania lub sprzedaży w przyszłości.

Z przeprowadzonych dotychczas badań jak i poczynionych obserwacji, a także dostępnej literatury [Liszewski 1997; Zioło 2001] wynika, że o ile przez wiele lat prawie za naturalne uważano powrót takich gruntów do funkcji przemysłowej, o tyle w późniejszym okresie prawie regułą stało się wykorzystywanie takich powierzchni do celów nieprodukcyjnych, często usługowych. Interesującym przykładem przekształcenia terenu dużego przedsiębiorstwa w Słupsku jest Zakład Urządzeń Okrętowych „Sezamor”, który zajmował grunty rozciągające się od ulicy Szczecińskiej do ulicy Kołobrzeskiej.

Prowadzona przez przedsiębiorstwo produkcja obejmowała do niedawna 9 typów produktów podstawowych (np. łańcuchy kotwiczne, wyciagi łańcuszkowe, suwnice montażowe, żurawiki łodziowe itp.). Do głównych odbiorców wyrobów należały m.in. znane firmy zagraniczne, np. Wortelboer i Schmitt z Holandii, Centrometr z Anglii, Drekena i Barthels \& Louders z Niemiec czy Billora z Rosji.

W wyniku przeprowadzonej restrukturyzacji majątkowej, przy znacznym spadku zatrudnienia z 364 osób w 1994 r. do 200 osób w 2002 r., nastapiło radykalne zmniejszenie o 2/3 powierzchni terenów przemysłowych dawnego zakładu. Dokonana została rozbiórka budynków fabrycznych, a na części uporządkowanego terenu powstały obiekty handlowe zajmujące się sprzedażą wyrobów z drewna (firma „Westprofil”) oraz stacja paliw Shell. Pozostała część terenu po dawnych halach produkcyjnych sprzętu okrętowego oczekuje na zagospodarowanie. W budynku głównym, w którym mieściła się dyrekcja zakładu, część obiektu przeznaczono na salon samochodowy Mitsubishi (obecnie w likwidacji). Na terenie zakładu powstały także Zakłady Poligraficzne Laminopol, Zakład Produkcji Obuwia „FORMA” oraz kolejny salon samochodowy Honda Igmar.

Na szersze omówienie zasługują procesy przekształceń największego zakładu przemysłowego Słupska, jakim była do 1994 r. Fabryka Obuwia „Alka” S.A. (1250 osób zatrudnionych). Godnym podkreślenia jest fakt, że istotną rolę w funkcjonowaniu przedsiębiorstwa było jego wejście do grupy kapitałowej „POT” BUT-S S.A. z Łodzi, która jest potentatem w produkcji obuwia damskiego, męskiego i młodzieżowego. W ramach przekształceń, w które zaangażowały się władze miasta, opracowano m.in. kilka koncepcji zagospodarowania kwartałów przemysłowych (ryc. 4). Miasto nabyło również niektóre nieruchomości, np. Szkołę Przyzakładową (dawny Zespół Szkół Obuwniczych), a także przedszkola.

Realizowana w dalszym ciągu strategia odchudzania przedsiębiorstwa doprowadziła w 1994 r. do sprzedaży majątku zakładowego oraz jego dzierżawy innym podmiotom gospodarczym. Obok przekształceń całych kwartałów lub budynków przemysłowych doszło także do podziału nieruchomości między większą liczbę średnich firm nabywających lub dzierżawiących obiekty od ich dysponenta (tab. 3). Mieszczą się tu m.in. dwie szkoły, biura M\&S Pomorskiej Fabryki Okien oraz przedsiębiorstwa handlowo-usługowe. Z badań jakie przeprowadzono na terenie Fabryki Obuwia „Alka” S.A. wynika, że w dzierżawie znajduje się około 43\% gruntów i powierzchni zabudowanych należących niegdyś do Fabryki Obuwia „Alka” S.A., zaś około 10\% powierzchni poprzemysłowej zostało sprzedane. 


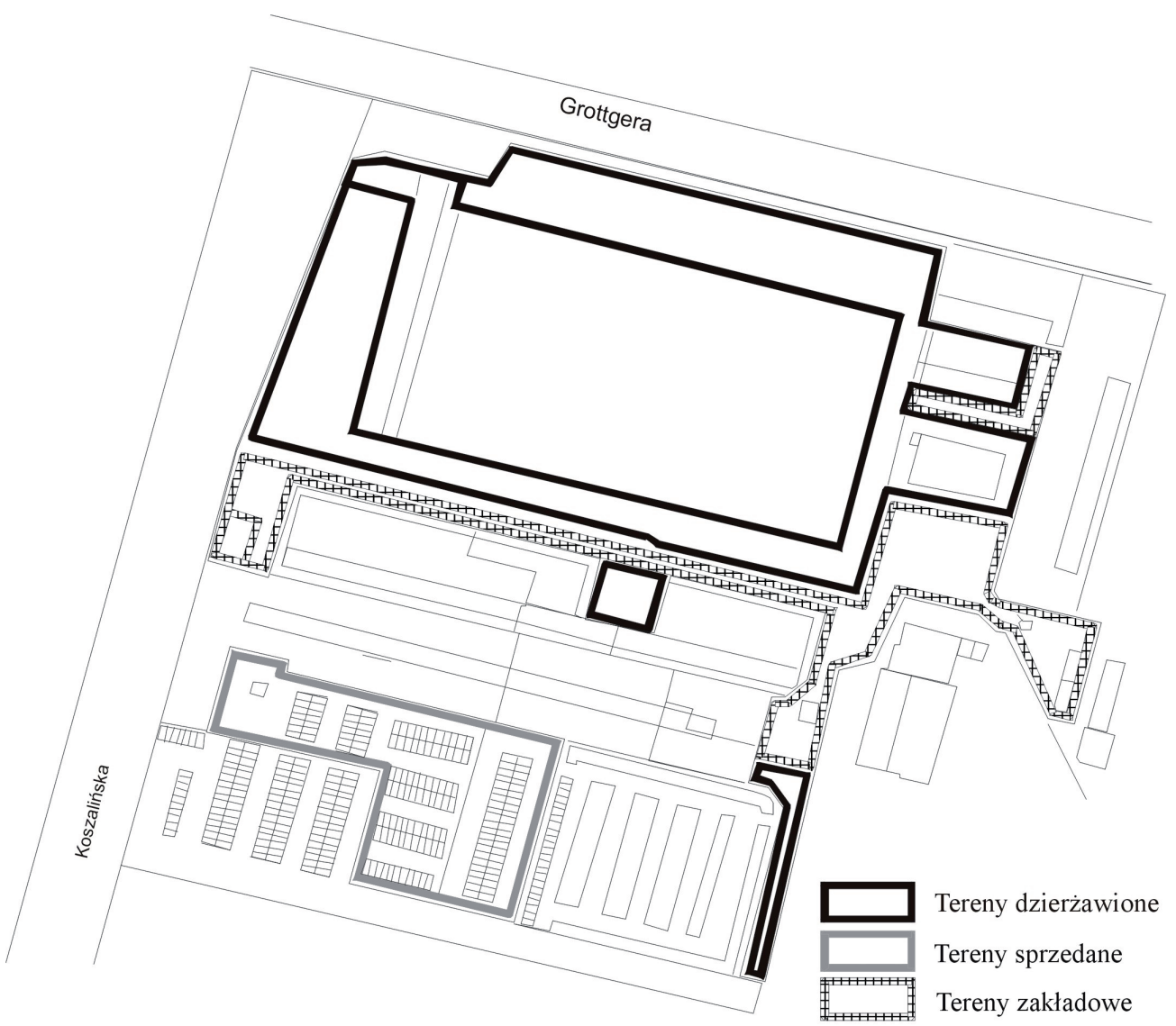

Ryc. 4. Plan sytuacyjny rozdysponowania gruntów po Zakładach Przemysłu Skórzanego „Alka’ w Słupsku w 2004 r.

Źródło: Opracowanie własne

Wyraźna zmiana użytkowania terenów przemysłowych nastąpiła również w Fabryce Maszyn Rolniczych „Famarol” S.A. położonej między ulicą Przemysłową a ulicą Poznańską na osiedlu Nadrzecze. Restrukturyzacja majątku trwałego prezentowanego zakładu, który rozpoczął działalność już w 1947 r., zapoczątkowana została w 1994 r. W pierwszym etapie obejmowała sprzedaż krajalni i łłoczni, prototypowni i składu złomu. W kolejnych latach wydzierżawiono magazyn farb, 1/3 część biurowca, m.in. dla Zespołu Szkół Niepublicznych oraz produkcyjny magazyn operacyjny. Kolejnym istotnym etapem restrukturyzacji zakładu był fakt przekształcenia się narzędziowni w spółkę z kapitałem obcym. W ramach postępującej restrukturyzacji majątku trwałego zakładu nastąpiło zmniejszenie powierzchni przemysłowej Fabryki Maszyn Rolniczych „Famarol” S.A. o ponad 43\%, w tym powierzchni pod dachem o 40\% (z $44621 \mathrm{~m}^{2}$ do $26621 \mathrm{~m}^{2}$ ). W części obiektów sprzedanych i wydzierżawionych powstały hurtownie materiałów budowlanych, zakłady naprawcze i rzemieślnicze, a także hurtownia materiałów metalowych CENTROSTAL. Część powierzchni poprzemysłowej atrakcyjnie zlokalizowanej przy ulicy Poznańskiej wykorzystana jest jako przestrzeń 
biurowca wynajmowana różnym firmom i instytucjom, m.in. Zarządowi Słupskiej Specjalnej Strefy Ekonomicznej.

Tabela 3. Wykaz najważniejszych dzierżawców Fabryki Obuwia „Alka” S.A. w 2002 r.

\begin{tabular}{|c|c|c|c|c|c|}
\hline \multirow[b]{2}{*}{ Dzierżawca } & \multicolumn{5}{|c|}{ Zajmowana powierzchnia $\left(\mathrm{w} \mathrm{m}^{2}\right)$} \\
\hline & Ogółem & Magazyny & Biuro & Teren, plac & $\begin{array}{l}\text { Droga, } \\
\text { korytarz }\end{array}$ \\
\hline $\begin{array}{l}\text { M\&S Pomorska } \\
\text { Fabryka Okien }\end{array}$ & 5286,0 & - & 5286,0 & - & - \\
\hline $\begin{array}{l}\text { Przedsiębiorstwo Handlowe } \\
\text { „Wega-Bis” }\end{array}$ & 3024,5 & 1500,1 & 271,4 & 1253,0 & - \\
\hline $\begin{array}{l}\text { Fabryka Podeszew } \\
\text { i Podpodeszew „EMEF” }\end{array}$ & 2080,4 & 1503,8 & - & 576,6 & - \\
\hline $\begin{array}{l}\text { Hurtownia } \\
\text { „Eurocash” }\end{array}$ & 2620,0 & 2620,0 & - & - & - \\
\hline $\begin{array}{l}\text { Prywatne Liceum } \\
\text { Ogólnokształcące }\end{array}$ & 632,5 & - & 528,1 & - & 104,4 \\
\hline $\begin{array}{l}\text { Firma Handlowo-Usługowa } \\
\text { „Stop” }\end{array}$ & 600,0 & - & - & 600,0 & - \\
\hline $\begin{array}{l}\text { Hurtownia Motoryzacyjna } \\
\text { „Tadmot” }\end{array}$ & 569,0 & - & - & 569,0 & - \\
\hline $\begin{array}{l}\text { Usługi Motoryzacyjne } \\
\text { „U Saszy” }\end{array}$ & 569,0 & - & - & 569,0 & - \\
\hline $\begin{array}{l}\text { Centrum Kształcenia } \\
\text { Praktycznego }\end{array}$ & 525,7 & - & 447,3 & - & 78,3 \\
\hline $\begin{array}{l}\text { Produkcyjno-handlowe } \\
\text { usługi „Zip” }\end{array}$ & 478,8 & 478,8 & - & - & - \\
\hline
\end{tabular}

Źródło: Materiały z Działu Księgowości w Fabryce Obuwia „Alka” S.A., Słupsk 2002

Przykładem nieudanego zagospodarowania terenu pofabrycznego jest upadłość i likwidacja Słupskiej Fabryki Mebli - zakładu, który bardzo mocno wtopił się w krajobraz przemysłowy ośrodka słupskiego. Procesy restrukturyzacyjne polegające na wykorzystaniu inwestorów zagranicznych jak i kapitału krajowego doprowadziły w efekcie do całkowitego bankructwa zakładu, który jeszcze w pierwszej połowie lat 90. należał do dość dobrze prosperujących. Na części gruntów poprzemysłowych zlokalizowane zostały obiekty handlowe: „Biedronka” i „Komfort”, a pozostały teren czeka na zagospodarowanie. Najprawdopodobniej tereny te zostaną przeznaczone pod budowę kolejnego kompleksu handlowego, tak jak miało to miejsce po Zakładach Meblowych Słupskiej Fabryki Mebli przy ulicy Jaracza i Lutosławskiego, gdzie powstał market „Lidl”.

$$
* * *
$$

Przeprowadzone badania pokazują, że do najczęstszych kierunków współczesnych przekształceń terenów przemysłowych należy ich ponowne wykorzystanie dla innej działalności produkcyjnej lub przejęcie na cele magazynowe, handlowe, a niekiedy edukacyjne. 
Odtworzenie funkcji produkcyjnej na terenach poprzemysłowych zachodzi przede wszystkim dzięki powstaniu średnich i małych firm. Przykładami powstania nowych dużych obiektów na terenach poprzemysłowych w słupskim ośrodku przemysłowym są: M\&S Pomorska Fabryka Okien, a także wymienione wcześniej zakłady: „Bajcar”, „NordGlass” i „Łosoś” położone na terenie Słupskiej Specjalnej Strefy Ekonomicznej.

Udział drobnych podmiotów w postaci hurtowni i sklepów jest szczególnie duży w obiektach poprzemysłowych położonych przy trasach wylotowych z miasta, np. przy ulicy Poznańskiej po Zakładach Mięsnych, Fabryce Maszyn Rolniczych „Famarol”, czy przy ulicy Szczecińskiej na terenach należących w przeszłości do Zakładów Urządzeń Okrętowych „Sezamor” oraz Słupskiej Fabryki Obrabiarek. Natomiast przy ul. Bałtyckiej na gruntach po Okręgowej Spółdzielni Mleczarskiej zlokalizowane są dwie największe hurtownie materiałów budowlanych i wyposażenia wnętrz („Fimal” i „Rebis”).

Ważną cechą różnicującą zachodzące przekształcenia jest trwałość zagospodarowania [Domański 2001]. Z badań, jakie prowadzono na terenie Słupska wynika, że obok przekształceń o charakterze długofalowym, w wyniku których powstają nowe przedsiębiorstwa, budynki biurowe, banki itd., istnieje także cała gama względnie nietrwałego doraźnego zagospodarowania, np. dzierżawa pod drobną działalność handlowo-usługową i magazynową przy ul. Pomorskiej, Przemysłowej czy Poznańskiej.

Zaobserwować można, że trwałość zagospodarowania ma dość ścisły związek z wielkością inwestycji oraz stosunkami własnościowymi. Zdecydowanie większa trwałość występuje w przypadku firm kupujących na własność lub biorących teren w użytkowanie wieczyste w celu prowadzenia własnej działalności na większą skalę, niż w przypadku słabych podmiotów gospodarczych, dzierżawiących nieruchomość czasami w celu ich podnajmowania.

Zaznaczyć należy, że trudności w zagospodarowaniu terenów poprzemysłowych wynikają także z działań firm będących właścicielem tych terenów. Odrębnym problemem są trudności w zagospodarowaniu byłych terenów poprzemysłowych $\mathrm{z}$ istniejącymi jeszcze obiektami wpisanymi do rejestru zabytków (np. Browar Słupski). Działania takie dopuszczają do daleko posuniętej dekapitalizacji zabudowy i infrastruktury nieużytkowanego terenu.

Przedstawiony proces przekształceń w użytkowaniu terenów przemysłowych Słupska wyraźnie wskazuje, iż tempo i charakter zachodzących zmian zależy od położenia terenu w strukturze przestrzennej miasta. Najsilniejsze przekształcenia w użytkowaniu terenów przemysłowych dokonały się z jednej strony na starej tkance miejskiej Słupska, gdzie praktycznie nastapiła prawie niemal całkowita zmiana charakteru ich wykorzystania, z drugiej zaś - na terenach dużych do niedawna przedsiębiorstw. Na podkreślenie zasługuje również fakt nowego zagospodarowania przemysłowego zarówno w budynki i budowle, jak i wszelką infrastrukturę terenów położonych na obrzeżach miasta, przy drogach wylotowych w kierunku na Piłę - Poznań, Szczecin i Ustkę. Warto tu podkreślić, że na terenach tych dokonują się zarówno zmiany własnościowe, jak i form użytkowania działki.

\section{Literatura}

Domański B. 2000, Tereny poprzemysłowe w miastach polskich - kierunki i bariery przeksztatceń, [w:] XIII Konwersatorium Wiedzy o Mieście. Miasto postsocjalistyczne. Organizacja przestrzeni miejskiej i jej przemiany, Katedra Geografii Miast i Turyzmu Uniwersytetu Łódzkiego, Łódź

Domański B. 2001, Przeksztatcenia terenów przemysłowych w województwach ślaskim i małopolskim - prawidłowości i uwarunkowania, [w:] Problemy przemian struktur przemystowych w procesie 
wdrażania reguł gospodarki rynkowej, red. Z. Zioło, Prace Komisji Geografii Przemysłu PTG, nr 3, Warszawa-Kraków-Rzeszów

Gasidło K. 1998, Problemy przeksztatceń terenów poprzemysłowych, Zeszyty Naukowe Politechniki Śląskiej, ,Architektura”, nr 37

Liszewski S. 1997, Przemiany funkcjonalne i przestrzenne terenów przemystowych Łodzi, [w:] Aglomeracje miejskie w procesie transformacji, red. P. Korcelli, IGiPZ PAN, z. 46, Warszawa

Rajman J. 2001, Zmienna rola przemystu jako czynnika miastotwórczego, [w:] Polska-Europa. Gospodarka, przemyst, red. J. Rajman, Wydawnictwo Naukowe Akademii Pedagogicznej w Krakowie, Kraków

Rydz E. 1990, Funkcje Koszalina i Stupska w regionalnej sieci osadniczej, Wyższa Szkoła Pedagogiczna w Słupsku, Słupsk

Rydz E. 1999, Przeobrażenia struktury wewnętrznej Szczecinka i Stupska w okresie transformacji gospodarczej, [w:] XII Konwersatorium Wiedzy o Mieście. Przestrzeń miejska, jej organizacja i przemiany, Katedra Geografii Miast i Turyzmu Uniwersytetu Łódzkiego, Łódź

Rydz E., Barańska P. 2000, Wybrane problemy przemystu mleczarskiego województwa stupskiego w latach 1990-1996, [w:] Problemy transformacji struktur przemystowych w procesie przechodzenia do gospodarki rynkowej, red. Z. Zioło, Prace Komisji Geografii Przemysłu PTG, nr 1, Warszawa-Kraków

Rydz E., Jażewicz I. 1997, Procesy transformacji stupskiego ośrodka przemysłowego w latach 1990 1995, [w:] Problemy transformacji struktur przemystowych $w$ procesie przechodzenia do gospodarki rynkowej, red. Z. Zioło, Komisja Geografii Przemysłu PTG i Instytut Geografii WSP w Krakowie, Warszawa-Kraków

Rydz E., Szymańska W. 2002, Funkcjonowanie zakładów przemysłu obuwniczego regionu stupskiego $w$ zmieniajacych sie warunkach gospodarowania, [w:] Problemy przemian struktur przemystowych w procesie wdrażania regut gospodarki rynkowej, red. Z. Zioło, Prace Komisji Geografii Przemysłu PTG, nr 4, Warszawa-Kraków-Rzeszów

Rydz E., Zaleski J. 1992, Rola i funkcje Stupska na tle sieci osadniczej Środkowego Wybrzeża, WSP, Słupsk

Zioło Z. 2001, Struktura branżowa i koncentracja przestrzenna wiodacych światowych firm przemystowych, [w:] Problemy przemian struktur przemysłowych w procesie wdrażania regut gospodarki rynkowej, red. Z. Zioło, Prace Komisji Geografii Przemysłu PTG, nr 3, Warszawa-KrakówRzeszów

\section{The effects of Slupsk industrial centre's restructurisation during the period of introducing the market economy (on selected examples)}

Our country's economical system's transformation, the purpose of which is to achieve conditions adequate to market economy, brought the necessity to restructurise a vast area of communal and economic Polish domains. Industry is one of these sectors, whose transformation's spatial results are immediately noticeable. It is due not only to change with internal economic mechanisms, but likewise to the global process of constant changing, which has firm influence on structure and spatial connections in industry. The article presents a research of spatial departments' structure and its modification on the example of Slupsk, concentrating particularly on the period of 1995-2003. It also describes ways to exploit the property of biggest factories, which were restructurised and allowed changing their function in using Słupsk industrial area. 